\title{
Germination of Croton urucurana L. seeds exposed to different storage temperatures and pre-germinative treatments
}

\author{
SILVANA P.Q. SCALON ${ }^{1}$, ROSILDA M. MUSSURY ${ }^{2}$ AND ANDRÉA A. LIMA ${ }^{3}$ \\ ${ }^{1}$ Programa de Pós-Graduação em Produção Vegetal, Universidade Federal da Grande Dourados/UFGD, \\ Faculdade de Ciências Agrárias, Rodovia Dourados-Itahum, Km 12, 79804-970 Dourados, MS, Brasil \\ ${ }^{2}$ Programa de Pós-Graduação em Biologia Geral/Bioprospecção, Universidade Federal da Grande Dourados/UFGD, \\ Faculdade de Ciências Biológicas e Ambientais, Rodovia Dourados-Itahum, Km 12, 79804-970 Dourados, MS, Brasil \\ ${ }^{3}$ Universidade Federal da Grande Dourados/UFGD, Faculdade de Ciências Biológicas e Ambientais, \\ Rodovia Dourados-Itahum, Km 12, 79804-970 Dourados, MS, Brasil
}

Manuscript received on May 5, 2010; accepted for publication on March 1, 2011

\begin{abstract}
The present work evaluated the germinability and vigor of Croton urucurana seeds. 1) Seeds were sorted by color (caramel, gray and black) and were subjected to seven different pre-germination treatments followed by incubation at $20^{\circ} \mathrm{C}, 25^{\circ} \mathrm{C}$ or $20 / 30^{\circ} \mathrm{C}$. 2) Seeds were stored in cold chambers or at room temperature for up to 300 days and were subsequently incubated at $20 / 30^{\circ} \mathrm{C}$ in a germination chamber or under greenhouse conditions. Only gray seeds showed significant germination rates. The highest first count percentages of total germination and the highest germination speed indices were observed in control seeds and in those which were treated with water or $200 \mathrm{mg} . \mathrm{L}^{-1}$ gibberellic acid for 12 hours. Seeds stored under refrigeration showed the highest values for all of the characteristics examined, as well as less electrical conductivity of the imbibing solution. Seedlings were more vigorous when seeds were stored for 300 days in a cold chamber. The seedlings production can be increased by incubating the seeds at alternating temperatures $\left(20 / 30^{\circ} \mathrm{C}\right)$. The seeds do not need pre-germination treatments.
\end{abstract}

Key words: gibberellic acid, refrigeration, "sangra d'água".

\section{INTRODUCTION}

Croton urucurana Baill (Euphorbiaceae), commonly known as "sangra d' água", "sangue-de-dragão" (dragon's blood), or urucurana is highly indicated for regenerating gallery forests and is specifically protected by the Brazilian environmental legislation. It is an arboreal, pioneer, deciduous, heliophyte

Correspondence to: Rosilda Mara Mussury

Email: maramussury@ufgd.edu.br and selective hygrophyte species that can improve soil conditions and help to prepare the environment for later successional species (Lorenzi 1992). The resin and stem bark of $C$. urucurana are used in popular medicines to staunch bleeding, promote healing, prevent infections, and treat stomach and intestine ulcers, and they also have antibacterial, anti-hemorrhagic, antiviral and antioxidant activities (Lorenzi and Matos 2002). 
Plants growing in natural environments often have cyclical sequences of seed production with one episode of high productivity followed by one or two years of low seed set, making it important for growers to maintain seed viability during storage through the use of specific technologies developed for each species (Kissmann et al. 2009). As the seeds of many species may not be sown immediately after maturation, they must be stored in appropriate ways to avoid deterioration (Baudet 2003). It has been established that there are often variations in the germinative potential of seeds according to the color of their teguments, which may be a sign of their degree of ripeness (Negrelle et al. 1999, Silveira et al. 2002) Pinho et al. (2009) noted that seed viability is lost during storage at room temperature or during extended storage periods, although the deterioration index varies from one species to the next. The temperature and relative humidity of the environment have important roles in determining seed longevity, and high humidity and temperatures during storage tend to accelerate seed deterioration.

Seeds tend to lose humidity after ripening, which may disrupt the cell membrane and lead to electrolyte leakage from the cells to the external environment. This process results in a loss of seed quality that is directly measurable by an increase of leachates in imbibed water.

Research carried out with different species has shown that decreases in germination and vigor are directly proportional to increases in solute release, and that conductivity evaluations are efficient for determining seed lot vigor. As such, seed damage may be evaluated by measuring any increase in the electric conductivity of the imbibed water (Vieira 1994).

Our current knowledge of the viability and storage potential of $C$. urucurana seeds is very limited, and the present work provides information about the influence of seed color, pre-germinative treatments, incubation temperatures, and storage time on their germination.

\section{MATERIALS AND METHODS}

The experiments were carried out in the Seed Laboratory of Faculdade de Ciências Agrárias at Universidade Federal da Grande Dourados, Mato Grosso do Sul State, Brazil.

The seeds were obtained from fruits collected from various trees along the Dourados/Itahum highway (Km 12) and on the Areeira Farm (approx. $-22^{\circ} 13^{\prime} 16^{\prime \prime} \mathrm{x}-54^{\circ} 48^{\prime} 2^{\prime \prime}$, at $452 \mathrm{~m}$ a.s.1.). The regional climate is classified as CWa (temperate humid climate with dry winters and warm summers), with an average rainfall of $1500 \mathrm{~mm}$ and an average annual temperature of $22^{\circ} \mathrm{C}$.

The fruits were collected in February 2006, stored under dry conditions in nylon sacks until their spontaneous opening released their seeds; this process took about 15 days. The seeds used in the experiments were separated into three groups according to their color: caramel, gray or black.

\section{GERMINATION TESTS BEFORE STORAGE}

Sixty days after harvesting the fruit crop, three different seed color groups were exposed to the following treatments: 1) immersion in water for 2 hours; 2) immersion in water for 12 hours; 3) immersion in a $200 \mathrm{mg} . \mathrm{L}^{-1}$ gibberellic acid (GA) solution for 2 hours; 4) immersion in a $200 \mathrm{mg} . \mathrm{L}^{-1}$ gibberellic acid (GA) solution for 12 hours; 5) immersion in a $1 \%$ potassium nitrate $\left(\mathrm{KNO}_{3}\right)$ solution for 2 hours; 6) immersion in a $1 \% \mathrm{KNO}_{3}$ solution for 12 hours; 7) control (no treatment). Seeds were subsequently sown into 'gerbox' trays lined with two sheets of filter paper and were incubated in a germination chamber with alternating regimes of 8 hours at $20^{\circ} \mathrm{C}$ in the dark and 16 hours at $30^{\circ} \mathrm{C}$ in the light, or at $20^{\circ} \mathrm{C}$ or $25^{\circ} \mathrm{C}$ under constant light; the filter paper had been humidified with 2.5 times its weight in water. Each of the three seed colors were exposed to the 7 pre-germination treatments and the 3 incubation temperatures $\left(20^{\circ} \mathrm{C}, 25^{\circ} \mathrm{C}\right.$ and $\left.20 / 30^{\circ} \mathrm{C}\right)$ using three 
replicates of 25 seeds. The germination percentages at the first count (14 days after sowing) and final count and their germination speed indices (GSI) were evaluated according to Popinigis (1985); the percentage data were arcsine converted.

\section{StORAGE TESTS}

In the storage experiments, the recently harvested seeds were stored in either a cold chamber at 16 $\pm 2^{\circ} \mathrm{C}$ and $69 \%$ of relative humidity or at room temperature $\left(23.5\right.$ to $\left.27.5^{\circ} \mathrm{C}\right)$ for $120,180,240$ and 300 days. After each storage period, the seeds were treated with $1 \%$ sodium hypochlorite for 10 minutes to disinfect them (Brasil 1992) and then submitted to a simple pre-germination treatment that consisted of imbibing the seeds in water for 24 hours. The seeds were then sown under two distinct germination conditions: 1) into 'gerbox' trays lined with two sheets of filter paper wetted with 2.5 times their weight with water and kept in a germination chamber with an alternating regimes of 8 hours at $20^{\circ} \mathrm{C}$ in the dark and 16 hours at $30^{\circ} \mathrm{C}$ in the light, for 30 days (when the germination percentage was found to stabilize); 2) into polystyrene trays containing plantmax ${ }^{\circledR}$ substrate, under greenhouse conditions, for 30 days. Four replications of 25 seeds were used in all tests.

\section{CONDUCTIVITY TESTS}

Before sowing, each seed lot was tested for its electrical conductivity as determined by immersing 50 previously weighed seeds in $75 \mathrm{~mL}$ of deionized water. The seeds were kept immersed at room temperature for 1, 4, 6 and 8 hours (adapted from Loeffler et al. 1988), and after each period the electrical conductivity of the water was measured using a Marconi CA150 conductimeter; this procedure was carried out four times for each of the storage conditions examined. The electrical conductivity based on the wet weight of the seeds was calculated by dividing the conductivity by the initial seed weight. The data obtained for each parcel were estimated as $\mu \mathrm{S} \mathrm{cm}^{-1}$.

\section{TESTS OF GERMINATION AND EMERGENCE}

The germinated and emerged seedlings were counted at every two days to evaluate the germination percentage (\%), the germination speed index (GSI) and the seedling emergence index (SEI) $(=\Sigma$ ni/ti where $n_{1} / N_{1}+n_{2} / N_{2}+\ldots n_{n} / N_{n}$, and $n_{1}, n_{2} \ldots n_{n}$ are equal to the numbers of germinated seeds, and $\mathrm{N}_{1}, \mathrm{~N}_{2}$ ... $\mathrm{N}_{\mathrm{N}}$ are the numbers of days) following Maguire (1962) and Popinigis (1985); after each evaluation, two seedlings from each replication and treatment were evaluated to determine their fresh and dry weights. For the seedlings grown under greenhouse conditions, the lengths of the aerial portions and the roots were also evaluated four weeks after the germination evaluations. The first count germination was carried out together with the germination test, which consisted of the percentage record of the normal seedlings, fourteen days after the sowing.

The outcomes were submitted to a variance analysis (Banzato and Kronka 2006) and the means were compared using the Tukey test at a 5\% probability level. Temperature monitoring was carried out at every two weeks using a digital thermohygrograph.

\section{RESULTS AND DISCUSSION}

Only the gray seeds germinated. This variability of seed germinative potential according to seed color has been observed in various species. Negrelle et al. (1999) observed that Maytenus ilicifolia Mart. seeds with chestnut pericarps had $98 \%$ germination rates, in contrast to greenish seeds (28\%). Similar results were reported by Silveira et al. (2002) for Calendula officinallis L., with the germination of cream-colored seeds being higher and suggesting that the change from green to a cream color is a good sign for harvesting mature seeds. These authors also noted that numerous workers correlated the physical, 
morphological and physiological characteristics of seeds to their ripening, and correlations between color and physiological ripeness have been noted for corn, wheat, oats, rice and soy beans.

Figure 1 shows that seeds incubated at $20-30^{\circ} \mathrm{C}$ and that were not exposed to any treatment except plain water, as well as those treated with GA 200 (both of these for 12 hours), began to germinate after 14 days. The number of germinated seeds increased until the $21^{\text {st }}$ day and then stabilized until the end of the evaluation period. Germination was only observed on the $21^{\text {st }}$ day in the other treatments and remained constant until the end of the evaluation period (except for the seeds treated with GA 200 for 2 hours). Although the period necessary for the Croton urucurana seeds to germinate was found to be similar to that previously published in the literature, the percentage germination in the present study was lower. Durigan et al. (2002) observed that seeds immersed in cold water for 2 hours before sowing accelerated and made germination more uniform (and generally greater than $80 \%$ ), taking from 10 to 20 days.

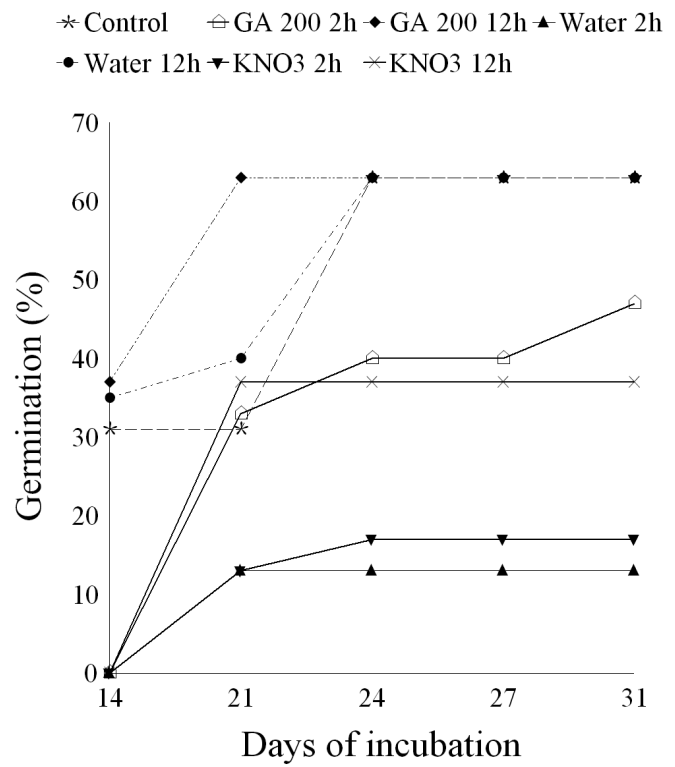

Fig. 1- Percentage of Croton urucurana Baill, seeds germinated in each pre-germinative treatment (water and GA - gibberellic acid) and incubated at $20 / 30^{\circ} \mathrm{C}$ during the experiment.
Germination was observed at $20^{\circ} \mathrm{C}$ only in treatments with $200 \mathrm{mg} . \mathrm{L}^{-1}$ GA for 2 hours $(10 \%)$, $1 \% \mathrm{KNO}_{3}$ for 12 hours, water for 12 hours $(6.3 \%)$, $200 \mathrm{mg} . \mathrm{L}^{-1}$ GA for 2 hours and control (3\%). In addition to germination being very low, the seedlings did not survive. Germination was not observed in any treatment at $25^{\circ} \mathrm{C}$ (data not presented here).

Based on ANOVA, all the evaluated characteristics demonstrated significant differences $(\mathrm{p}<0.05)$ among the different treatments (except for seedlings survival). Higher percentages of total germination and GSI were noted during the first count when the seeds were treated by immersion in water and in GA for 12 hours, as well as among those not exposed to any treatment (control). All of the seedlings survived in all of these treatments (Table I). According to our results, C. urucurana seeds require temperature fluctuations in order to germinate. However, as the germination index was generally low, it may be that the thermal bands used here did not coincide with the species' optimums.

Similar to Bixa orellana L. (Gomes and Bruno 1992) and Sebastiania commersoniana Braill. \& Downs (Santos and Aguiar 2000), C. urucurana seeds germinated better when exposed to an alternating temperature regime. While studying the germination of Muntingia calabura L. seeds, Lopes et al. (2002) observed higher germination percentages and germination speed indices at $20 / 30^{\circ} \mathrm{C}$, but no germination at $20^{\circ} \mathrm{C}$ on the substrate tested. However, these authors observed better results when they associated alternating temperatures with the treatments with $0.2 \%$ $\mathrm{KNO}_{3}$. Similarly, Scalon et al. (2007) observed that, on the average, germination percentages of Dimorphandra mollis Benth. seeds were higher at $25^{\circ} \mathrm{C}$ and at $20 / 30^{\circ} \mathrm{C}$.

In relation to pre-germinative treatments, a favorable effect on seeds immersed only in water was also observed by Scalon et al. (2005a) with M. ilicifolia. These authors observed that seeds soaked in water for 12 hours (or in $\mathrm{KNO}_{3}$ ) had 
TABLE I

Total germination, germination on the first count and index of germination speed of Croton urucurana Baill. incubated at $20 / 30^{\circ} \mathrm{C}$.

\begin{tabular}{|c|c|c|}
\hline Treatments & $\begin{array}{c}\text { Total germination } \\
(\%)\end{array}$ & $\begin{array}{l}\text { Germination on } \\
\text { the } 1^{\text {st }} \text { count }\end{array}$ \\
\hline
\end{tabular}

\begin{tabular}{lcccc}
\hline Control & $63.3 \mathrm{a}$ & $53.3 \mathrm{a}$ & $031 \mathrm{a}$ & 100 \\
GA 200mg.L ${ }^{-1} 2 \mathrm{~h}$ & $46.7 \mathrm{ab}$ & $23.3 \mathrm{ab}$ & $0.13 \mathrm{ab}$ & 100 \\
GA 200mg.L $\mathrm{L}^{-1} 12 \mathrm{~h}$ & $63.3 \mathrm{a}$ & $53.3 \mathrm{a}$ & $0.32 \mathrm{a}$ & 100 \\
KNO3 1\% 2 h & $16.7 \mathrm{~b}$ & $6.67 \mathrm{~b}$ & $0.07 \mathrm{~b}$ & 100 \\
KNO3 1\% $12 \mathrm{~h}$ & $36.7 \mathrm{ab}$ & $26.67 \mathrm{ab}$ & $0.17 \mathrm{ab}$ & 100 \\
Water 2 h & $13.3 \mathrm{~b}$ & $6.67 \mathrm{~b}$ & $0.07 \mathrm{~b}$ & 100 \\
Water 12 h & $63.3 \mathrm{a}$ & $53.33 \mathrm{a}$ & $0.31 \mathrm{a}$ & 100 \\
VC (\%) & 35.3 & 42.9 & 36.7 & \\
\hline
\end{tabular}

Means followed by the same small letter in the column are statistically equal by Tukey test at $5 \%$ of probability.

higher germination percentages and germination speed indexes with means that did not vary among themselves, but root and aerial portion lengths were higher when the seeds were treated with $250 \mathrm{mg} \mathrm{L}^{-1}$ GA. Similarly, Macedo et al. (2009) observed that Magonia pubescens St. Hil seeds that were immersed only in water showed the highest emergence values, although GA immersion gave higher height and fresh and dry weight values of the aerial portion.

Based on ANOVA, all the evaluated characteristics demonstrated significant interactions between the incubation environment and the storage period. In terms of stored seeds under both incubation conditions, it was observed that there were significant interactions for all of the characteristics evaluated (except for GSI and root size under greenhouse conditions).

Seeds stored in cold chambers had germination percentages higher than those stored at room temperature under both incubation conditions.
Storage at room temperature followed by incubation at $20 / 30^{\circ} \mathrm{C}$ resulted in a reduction on each evaluation, reaching $0 \%$ after 300 days of storage (Figure 2a). Seeds stored in the cold chamber demonstrated a linear increase of their germination percentages when incubated at $20 / 30^{\circ} \mathrm{C}$, while those incubated in the greenhouse demonstrated a reduction in their germination rate until 240 days, but increases thereafter (Figure 2b). Under these conditions, mean final germination percentages of $55.33 \%\left(20 / 30^{\circ} \mathrm{C}\right)$ and $49.25 \%$ (in the greenhouse) were observed.

The gradual decrease in the germination percentages of seeds stored at room temperatures is clearly visible at the time of the third evaluation, and suggests that deterioration became more pronounced after this time. The relatively quick deterioration at room temperature $\left(20^{\circ} \mathrm{C}\right.$ to $\left.25^{\circ} \mathrm{C}\right)$ in contrast to the efficient conservation of the physiological quality of the seeds in a cold chamber was also reported for Albizia hasslerii (Chod.) Burkart by Kissmann 

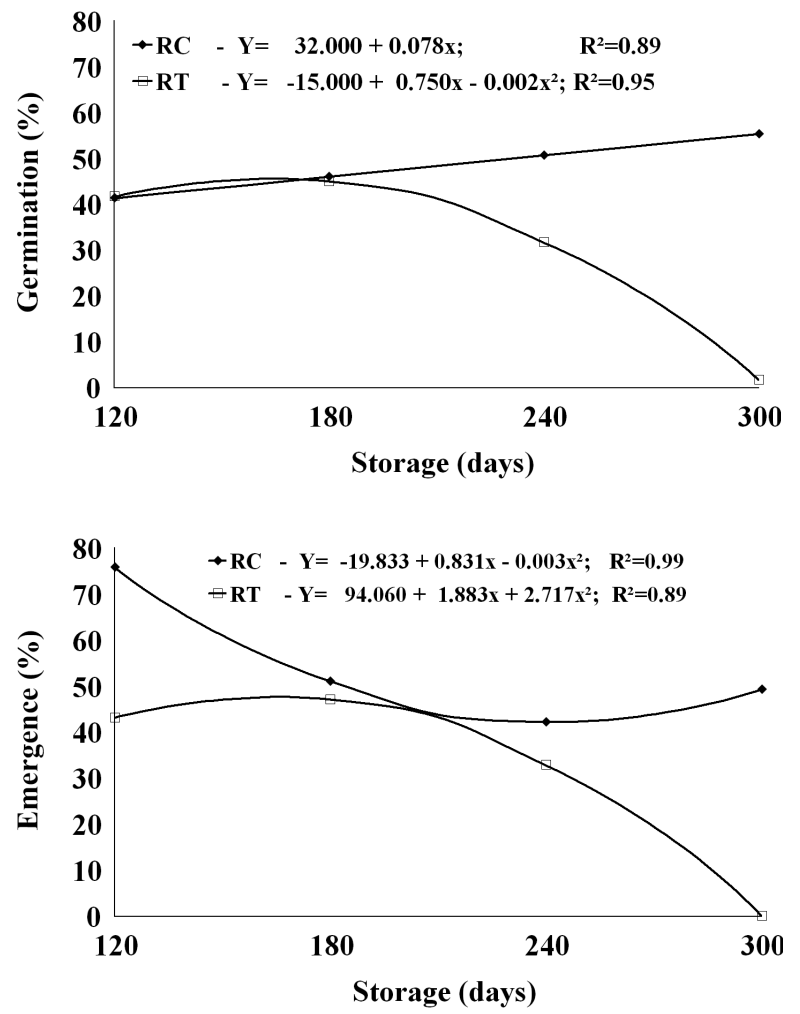

Fig. 2- Germination percentage of Croton urucurana seeds incubated at $20 / 30^{\circ} \mathrm{C}$ room temperature (a), and in under greenhouse condition (b) previously stored under refrigeration condition (RC) and at room temperature (RT).

et al. (2009), and for Jacaranda cuspidifolia Mart. by Scalon et al. (2006). Pinho et al. (2009), however, observed that the seeds of Adenanthera peregrina (L.) Speg. retained high germination percentages and high seed viability percentages (tetrazolium test) during five months of storage at both $5^{\circ} \mathrm{C}$ and $20^{\circ} \mathrm{C}$.

The observed reductions in seed viability after storage at room temperature may be the result of increased seed respiratory activity, with subsequent reductions of germinative quality as a consequence of an impoverishment of their metabolic reserves. Refrigeration, on the other hand, reduces the metabolic activity of the embryos and helps to maintain seed vigor (Scalon et al. 2006). However, even under refrigerated storage, seeds may lose their germinative capacity, as was observed with $D$. mollis Benth. (Scalon et al. 2007) and with Enterolobium contortilisiquum (Vell.) Morong (Scalon et al. 2005b).
Results similar to those of the germination percentages were observed with the values of the first germination counts of seeds incubated at $20 / 30^{\circ} \mathrm{C}$, where seeds previously stored in the cold chamber had higher percentages and increasing averages when compared to seeds stored at room temperature. After 240 days of storage, these values also began to decline for seeds stored in the cold chamber (Figure 3). Seeds germinated under greenhouse conditions did not show any significant differences between the treatments, having an average of $2.5 \%$ of emergence on the first count.

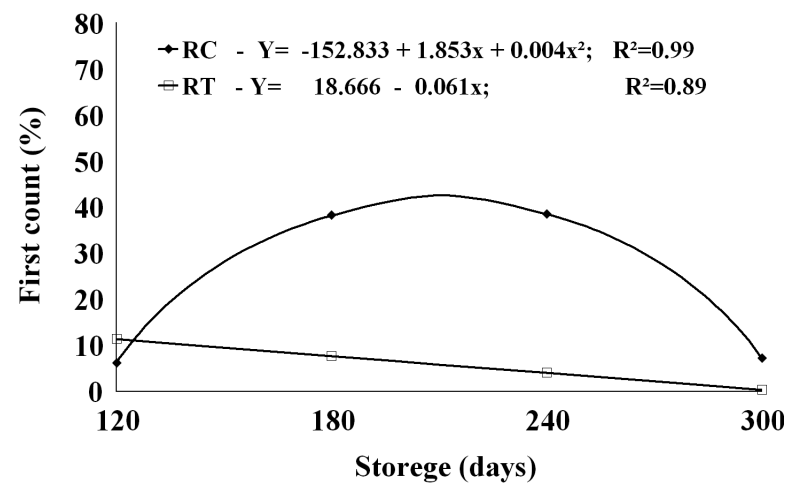

Fig. 3- First count of germination and emergence of Croton urucurana seeds incubated at $20 / 30^{\circ} \mathrm{C}$ previously stored under refrigeration condition (RC) and at room temperature (RT).

The low emergence percentages observed under greenhouse conditions on the first count may be explained by the fact that the seeds were exposed to temperature and humidity fluctuations that could reduce the speeds of the metabolic reactions necessary for seedling germination and emergence.

These results were supported by the observed reduction in the emergence speed index, as can be seen in Table I. Significant differences in GSI and IES values were observed depending on the pre-germination storage conditions, these values being higher in seeds held in the cold chamber and subsequently incubated under alternating temperatures $\left(20 / 30^{\circ} \mathrm{C}\right)$, where they had average rates that were higher $(0.478)$ than those of seeds incubated in the greenhouse (0.252). 
In relation to the period of seed storage, the GSI was lower in seeds incubated at $20 / 30^{\circ} \mathrm{C}$, while the seeds incubated under greenhouse conditions increased only until day 180 (Figure 4). It is probable that the natural nocturnal-diurnal thermal variations to which the germinating seeds were exposed under greenhouse conditions after 120 and 180 days of storage were lower than the natural thermal variations they experienced after 240 and 300 days of storage (and also lower than the controlled thermal variations in the germination chamber).

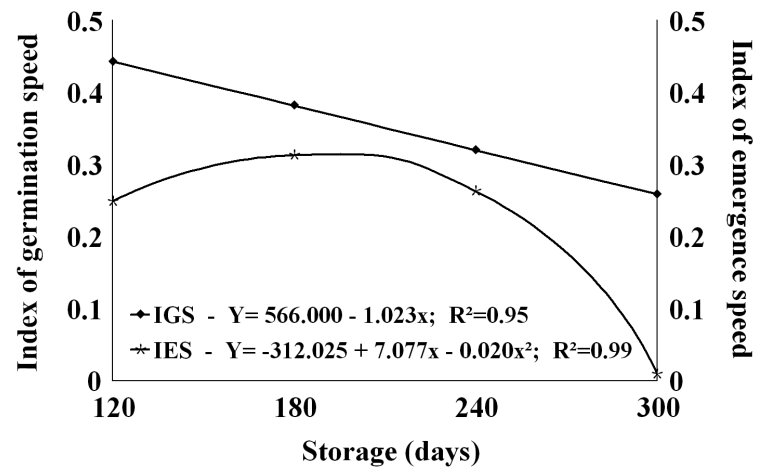

Fig. 4- Index of germination speed and index of emergence speed in Croton urucurana seeds incubated in BOD at $20 / 30^{\circ} \mathrm{C}$ in greenhouse.

Similar reductions in GSI during storage were also observed by Kissmann et al. (2009) with Albizia haslerii Chod. Burkart seeds, although the GSI values were higher at $25^{\circ} \mathrm{C}$ in all of the evaluation periods; Lopes and Pereira (2005) observed similar results for Solanum sessiliflorum Dunal seeds at $20 / 30^{\circ} \mathrm{C}$. Vásquez-Yanes and Orozco Segovia (1984) suggested that the high germination speed indexes of some species under alternating temperatures were due to enzymatic mechanisms favored by temperature fluctuations within specific thermal amplitudes.

The data concerning electrical conductivity indicated an increase in the amounts of electrolytes released by seeds during imbibition as they aged (Figure 5), a fact that was confirmed by several authors with seeds of other species (Simon and Raja-Harun 1972, Loeffler et al. 1988, Marcos Filho et al. 1990). It is important to stress, however, that electrolyte release was greater in seeds that were stored at room temperature for 240 days as compared to seeds stored under refrigeration for the same period of time.

After 300 days, however, the conductivities

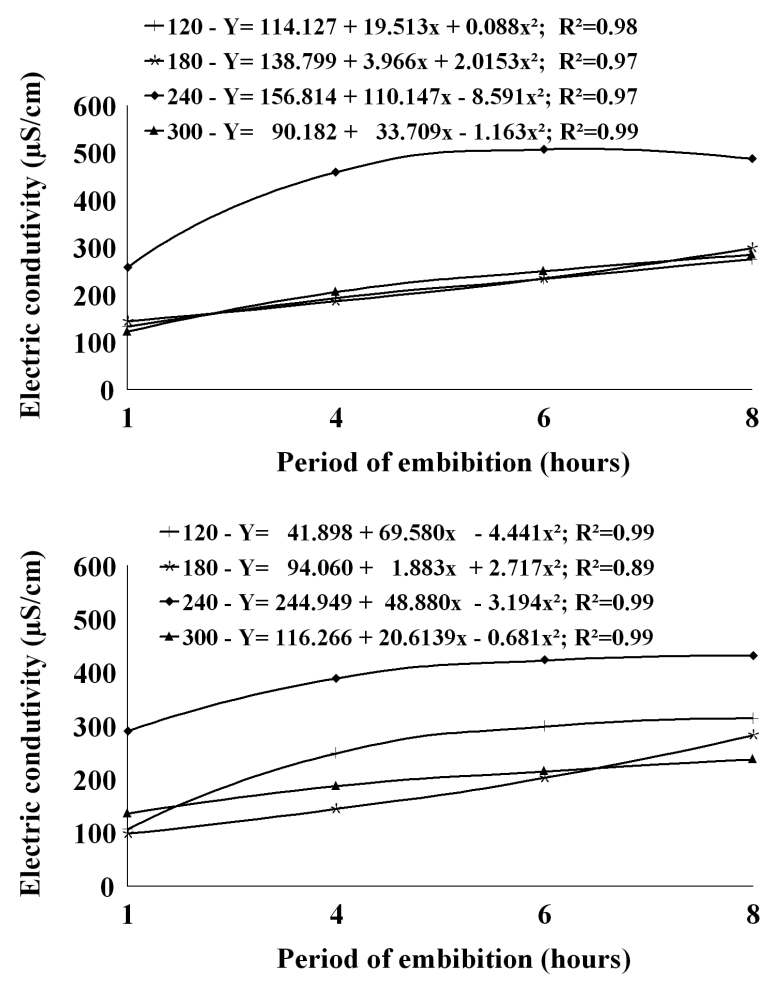

Fig. 5- Electric conductivity of Croton urucurana seeds under imbibition, stored at room temperature (a) and under refrigeration (b) at different periods.

of cold-stored seeds and seeds stored at room temperature were similar. Although the seeds of C. urucurana were originally collected in the same region, they were obtained from different plants and may show different physiological qualities at different ripening stages. Calendula officinallis (Silveira et al. 2002) and Dalbergia nigra (Vell.) Fr. All. Ex Benth. seeds (Marques et al. 2002) harvested in different years showed higher electrical conductivity values than seeds collected at different stages of physiological maturity. Silveira et al. (2002) observed that the size, color and water content of the seeds, as well as the lignin content on their tegument, affect their conductivity. Powell 
(1986) noted that high ionic concentrations in the exudates reflect the presence of deteriorated cell membranes - and therefore low-quality seeds; on the other hand, low electrolyte concentrations presume membrane integrity - which is a good sign of the safe maintenance of seed germinative capacity.

No significant differences were observed in the root sizes of seedlings from seeds stored under cold or room temperature conditions and subsequently incubated under greenhouse conditions, and root sizes progressively decreased during the evaluation period (Figure 6a). Kissmann et al. (2009) and Souza et al. (2005) likewise observed that the root lengths of A. haslerii and Tabebuia serratifolia Vahl. Nich seedlings decreased with seed storage time.

There was a significant effect of storage conditions on the size of the aerial portions of the seedlings, with a reduction in the sizes of these aerial portions being observed among seeds stored at room temperature, and an increase observed when they were stored under refrigeration (Figure 6b). Reductions in the size of the aerial portion reflect the loss of seed vigor and are consonant with the reduction in germination percentages and increasing electrical conductivity. Contrasting results of increases in the aerial portions were observed, however, in seeds stored under refrigeration, which indicates the maintenance of their vigor. Similar results were observed with the "farinha seca" seedlings (Kissmann et al. 2009). (Figure 6)

Seedlings grown from seeds stored in the cold chamber and germinated at $20 / 30^{\circ} \mathrm{C}$ showed reductions in their fresh weights (Figure 7) after up to 240 days of storage, but their fresh weights increased at the next evaluation (300 days). This reduction in fresh weight was observed until 180 days under greenhouse germination conditions, but increased at the next evaluation (240 days).(Figure 7)

Likewise, the dry weights of seedlings grown from seeds stored at room temperature decreased with increasing storage time. The dry weights of seedlings grown from seeds stored in the cold
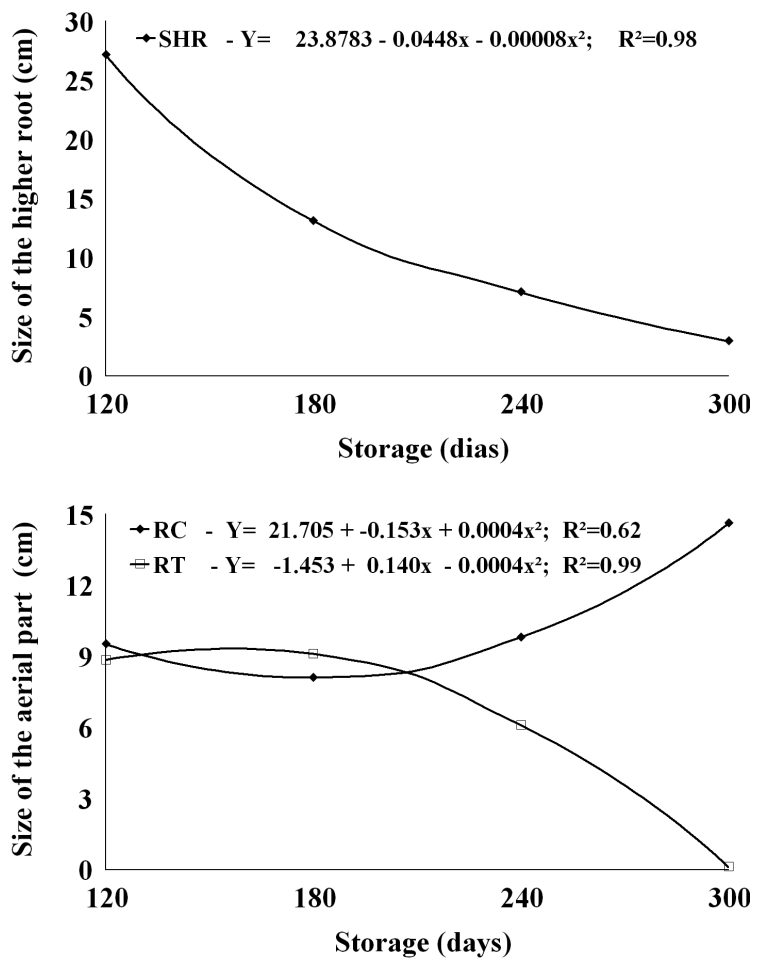

Fig. 6- Size of the higher root (a) and size of the aerial part (b) of Croton urucurana seedlings from the seeds stored at room temperature and under refrigeration condition and incubated in under greenhouse conditions.

chamber and then incubated at $20 / 30^{\circ} \mathrm{C}$ continually decreased for 240 days; the dry weights of seedlings grown from these same seeds but incubated under greenhouse conditions showed similar decreases with increasing storage time, but only up to 180 days, after which the seedlings began to show increases in dried weight in the following evaluations (Figure 8).

The seedlings grown under greenhouse conditions had higher fresh and dry weights due to longer periods of evaluation, which allowed them to accumulate more mass than the seedlings maintained in growth chambers under alternating temperatures. The increase in fresh weight was probably lower among seedlings grown under greenhouse conditions at natural environmental temperatures because the seeds were less vigorous due to greater losses of humidity (although this characteristic was not specifically evaluated). 

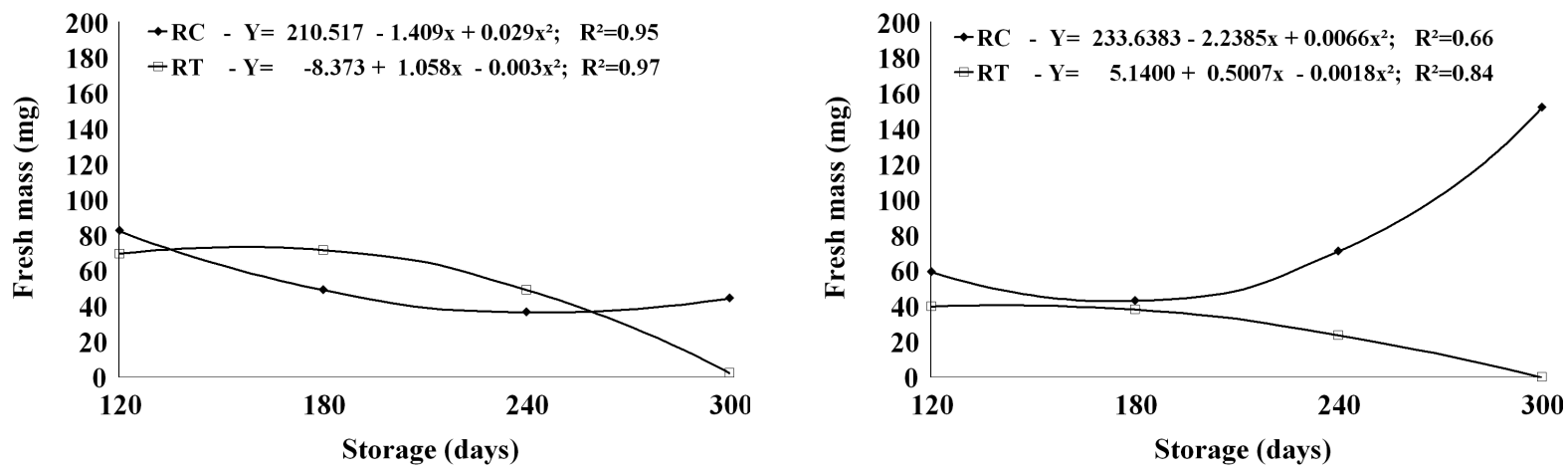

Fig. 7- Fresh mass of Croton urucurana seedlings from the seeds stored at room temperature (RT) and under refrigeration condition (RC) and incubated at $20 / 30^{\circ} \mathrm{C}$ (a) and in under greenhouse conditions (b).
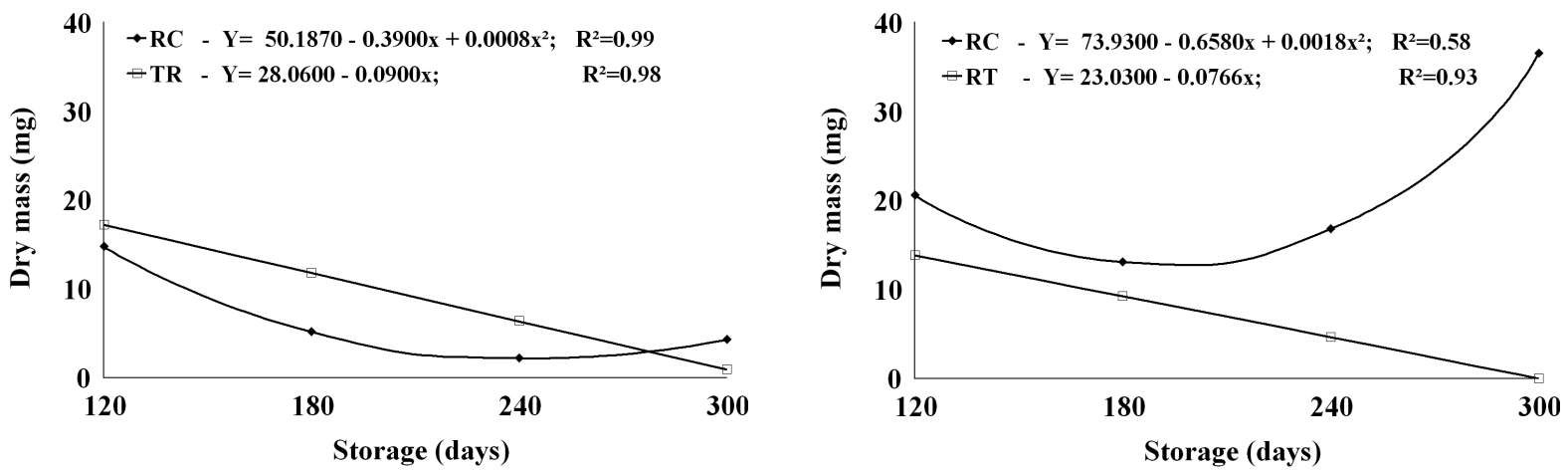

Fig. 8- Dry mass of Croton urucurana seedlings from the seeds stored at room temperature (RT) and under refrigeration condition (RC) and incubated at $20 / 30^{\circ} \mathrm{C}$ (a) and in under greenhouse conditions (b).

The incubation of C. urucurana seeds in trays with plantmax ${ }^{\circledR}$ under greenhouse conditions results in satisfactory seedling growth and is indicated for seedlings production due to its easy usage, while the same seedlings incubated in growth chambers demonstrated signs of rot, and even when transplanted to the soil substrate before this deterioration was visible they soon grew weak and died (data not presented).

\section{CONCLUSIONS}

Croton urucurana seedlings demonstrated greater vigor when the seeds had been stored for 300 days in a cold chamber.

The seedlings production can be increased by incubating the seeds at alternating temperatures $\left(20 / 30^{\circ} \mathrm{C}\right)$. The seeds do not need pre-germination treatments.

\section{ACKNOWLEDGMENTS}

We thank Fundação de Apoio ao Desenvolvimento do Ensino, Ciência e Tecnologia do Estado de Mato Grosso do Sul (FUNDECT) for the financial support.

\section{RESUMO}

O presente trabalho avaliou a germinação e vigor de sementes de Croton urucurana. 1) As sementes foram classificadas por cores (caramelo, cinza e preto) e foram submetidas a sete diferentes tratamentos prégerminativos seguidos de incubação a $20^{\circ} \mathrm{C}, 25^{\circ} \mathrm{C}$ e $20 / 30^{\circ} \mathrm{C}$. 2) As sementes foram armazenadas em câmaras frias ou em temperatura ambiente por até 300 dias e foram posteriormente incubadas a $20 / 30^{\circ} \mathrm{C}$ em câmara de germinação ou em condições de estufa. Somente sementes cinza apresentaram taxas significativas de germinação. As maiores percentagens de primeira contagem de germinação total e os maiores índices de velocidade de 
germinação foram observados em sementes de controle e naquelas que foram tratadas com água ou $200 \mathrm{mg} \mathrm{L}^{-1}$ de ácido giberélico por 12 horas. Sementes armazenadas sob refrigeração apresentaram os maiores valores para todas as características analisadas, assim como menor condutividade elétrica da solução de embebição. As plântulas foram mais vigorosas, quando as sementes foram armazenadas por 300 dias em câmara fria. A produção de mudas pode ser aumentada pela incubação das sementes em temperaturas alternadas $\left(20 / 30^{\circ} \mathrm{C}\right)$. As sementes não necessitam de tratamentos pré-germinativos.

Palavras-chave: ácido giberélico, refrigeração, “sangra d' água".

\section{REFERENCES}

BANZATO DA AND KRONKA SN. 2006. Experimentação Agrícola. $4^{a}$ ed., Jaboticabal: Funep, 237 p.

BAUDET L. 2003. Armazenamento de Sementes. In: Peske ST, Rosenthal MD and Rota GM (Eds), Sementes: fundamentos científicos e tecnológicos. Pelotas: Gráfica Universitária-UFPel, p. 369-418.

BRASIL. 1992. Ministério da Agricultura e Reforma Agrária. Regras para análise de sementes. Brasília: Coordenação de Laboratório Vegetal - CLAV. Departamento Nacional de Defesa Vegetal, 365 p.

DURigan G, Figliola MB, KaWABATA M, Garrido MAO AND BAITELlo UB. 2002. Sementes e mudas de árvores tropicais. São Paulo: Páginas \& Letras Editora e Gráfica, $2^{\mathrm{a}}$ ed., $65 \mathrm{p}$.

GOMES SMS AND BRUNO RL. 1992. Influência da temperatura e substratos na germinação de sementes de urucum (Bixa orellana L.). Rev Bras Sementes 14: 47-50.

KisSMANN C, SCALON SPQ, MuSSURY RM AND RoBAINA AD. 2009. Germinação e armazenamento de sementes de Albizia haslerii (Chod.) Burkart. Rev Bras Sementes 31: 104-115.

LOEFFLer TM, TEKRONY DM AND EGLi DB. 1988. The bulk conductivity test as an indicator of soybean seed quality. $\mathrm{J}$ Seed Technology 12: 37-53.

LOPES JC AND PEREIRA MD. 2005. Germinação de sementes de cubiu em diferentes substratos e temperaturas. Rev Bras Sementes 27: 146-150.

LOPES JC, PEREIRA MD AND MARTINS-Filho S. 2002. Germinação de sementes de Calabura (Muntingia calabura L.). Rev Bras Sementes 24: 59-66.

LORENZI H. 1992. Árvores brasileiras: manual de identificação e cultivo de plantas arbóreas nativas do Brasil. Nova Odessa: Plantarum.

LORENZI H AND MATOS FJA. 2002. Plantas medicinais no Brasil: nativas e exóticas. São Paulo: Instituto Plantarum de Estudos da Flora LTDA.

Macedo MC, Scalon SPQ, Sari AP, Scalon Filho H, RosA YBCJ AND RoBAINA AD. 2009. Biometria de frutos e sementes e germinação de Magonia pubescens St.Hil (Sapindaceae). Rev Bras Sementes 31: 202-211.

MAguiRE JD. 1962. Speed of germination aid in selection and evaluation for emergence and vigour. Crop Science 2: $176-177$.
Marcos Filho J, Silva WR, NOVEMBre ADCL AND CHAMma HMCP. 1990. Estudo comparativo de métodos para avaliação da qualidade fisiológica de sementes de soja, com ênfase ao teste de condutividade elétrica. Pesq Agropec Bras 25: 1805-1815.

Marques AM, Paula RC AND Rodrigues TJD. 2002. Adequação do teste de condutividade elétrica para determinar a qualidade fisiológica de sementes de Jacarandá-da-Bahia (Dalbergia nigra (Vell.) Fr. All. Ex Benth.). Rev Bras Sementes 24: 271-278.

Negrelle RRB, Doni ME, OHLSON OC AND HeRr S. 1999. Tecnologia de produção de sementes de espinheira-santa (Maytenus ilicifolia Mart. Ex. Reiss - Celastraceae). Rev Bras Sementes 21: 76-81.

Pinho DS, Borges EEL, CORTE VB AND NASSER LCB. 2009. Avaliação da qualidade fisiológica de sementes de Anadenanthera peregrina (L.) Speg. durante o armazenamento Rev Árvore 33: 27-33.

POPINIGS F. 1985. Fisiologia de Sementes. Brasília, Agriplan, $285 \mathrm{p}$.

PowEll AA. 1986. Membrana celular and seed leachate conductivity in relation to the quality of seed for sowing. J Seed Technology 10: 699-705.

SANTOS SRG AND AGUIAR IB. 2000. Germinação de sementes de branquilho (Sebastiania commersoniana (Baill) Smith \& Downs em função do substrato e do regime de temperatura. Rev Bras Sementes 22: 120-126.

SCALON SPQ, MuSSURY RM, SCALON FILHO H, FRANCELINO CSF AND FLORENCIO DKA. 2006. Armazenamento e tratamentos pré germinativo em sementes de jacarandá (Jacaranda cuspidifolia Mart.). Rev Árvore 30: 179-185.

SCALON SPQ, Mussury RM, WaThIER F, Gomes AA, SiLVA KA, Pierezan L AND SCALON Filho H. 2005b. Armazenamento, germinação de sementes e crescimento inicial de mudas de Enterolobium contortisiliquum (Vell.) Morong Acta Sci Biol Sci 27: 107-112.

SCALON SPQ, RAMOS MBM AND VIEIRA MC. 2005a. Germinação de sementes de Maytenus ilicifolia Mart. Ex. Reiss: armazenamento, embalagem e tratamentos prégerminativos. Rev Bras Plantas medicinais 7: 32-36.

SCAlON SPQ, SCALON FilHo H, Mussury RM, MaCEdo CM AND KisSIMANN C. 2007. Potencial germinativo de sementes de Dimorphandra mollis Benth. em armazenamento, tratamentos pré-germinativo e temperatura de incubação. Rev Cerne 13: 321-328.

Silveira MAM, ViLLELA FA AND TILLMANN MAA. 2002. Maturação fisiológica de sementes de calêndula (Calendula officinalis L.). Rev Bras Sementes 24: 31-37.

SIMON EW AND RAJA-HARUN RM. 1972.Leakage during seed imbibition. J Exp Bot 23: 1076-1085.

SouzA VC, BRuno RLA AND ANDRADE LA. 2005.Vigor de sementes armazenadas de ipê-amarelo Tabebuia serratifolia (Vahl.) Nich. Rev Árvore 29: 833-841.

VÁzQueZ-Yanez C AND OrOZCo-SEgOVIA A. 1984. Fisiologia ecológica de las semillas de árboles de la selva tropical: un reflejo de su ambiente. Ciência 35: 191-201.

VIEIRA RD. 1994. Teste de condutividade elétrica. In: VIEIRA RD and CARVALHO NM (Eds), Testes de vigor em sementes. Jaboticabal: FUNEP, p.103-132: Teste de condutividade elétrica. 